\title{
Priorities and sequencing in privatization: Evidence from Czech firm panel data
}

\author{
Nandini Gupta ${ }^{\mathrm{a}}$, Jhon C. Ham ${ }^{\mathrm{b}, *}$, Jan Svejnar ${ }^{\mathrm{c}}$ \\ ${ }^{a}$ Kelley School of Business, Indiana University, USA \\ ${ }^{\mathrm{b}}$ University of Southern California, USA, the Federal Reserve Bank of San Francisco, USA, and IZA \\ ${ }^{\mathrm{c}}$ University of Michigan, USA, CERGE-EI, CEPR, and IZA
}

Received 21 June 2004; accepted 14 May 2007

Available online 6 July 2007

\begin{abstract}
While privatization of state-owned enterprises has been one of the most important aspects of the economic transition from a centrally planned to a market system, no transition economy has privatized all its firms simultaneously. This raises the question of whether governments privatize firms strategically. In this paper we examine the determinants of the sequencing of privatization. To obtain testable predictions about the factors that may affect sequencing, we investigate the following competing government objectives: (i) Maximizing efficiency through resource allocation; (ii) maximizing public goodwill from the free transfers of shares to the public; (iii) minimizing political costs; (iv) maximizing efficiency through information gains; and (v) maximizing privatization revenues. Next, we use firm-level data from the Czech Republic to test the competing predictions about the sequencing of privatization. Consistent with the hypotheses of a government priority on revenues and public goodwill, we find strong evidence that more profitable firms were privatized first. The sequencing of privatization is also consistent with maximizing efficiency through information gains. Our results indicate that many empirical studies of the effects of privatization on firm performance suffer from a selection bias.
\end{abstract}

(C) 2007 Elsevier B.V. All rights reserved.

JEL classification: G38; L33; L51; P5

Keywords: Privatization; Political economy; Transition

\footnotetext{
${ }^{*}$ Corresponding author. Department of Economics, University of Southern California, 3620 S. Vermont Ave. KAP 300 Los Angeles, CA 90089. Tel.: +2137408335; fax: + 2137408543.

E-mail addresses: nagupta@indiana.edu (N. Gupta), johnham@usc.edu (J.C. Ham), svejnar@umich.edu (J. Svejnar).
} 


\section{Introduction}

While the privatization of state-owned enterprises (SOEs) has been one of the most important aspects of economic transition from a centrally planned to a market system, no government has privatized all its SOEs simultaneously. Even in countries that strove to privatize rapidly, (e.g., the Czech Republic, Estonia, Russia, and the Ukraine), the process consisted of a sequence of moves, with some firms being privatized earlier than others.

A government may sequence privatization of SOEs for a number of reasons. First, it may incur excessively high congestion and transaction costs if it tries to privatize all firms simultaneously. This was clearly a factor in the transition economies, such as the Czech Republic, Hungary, and Poland, and it is also true for countries with large state-owned sectors in other parts of the world, such as Brazil, China, and India. Second, a government may sequence privatization to reveal information about the firms to investors. If firms are sold sequentially, later buyers can observe the quality of the firms sold earlier. This informational advantage of sequencing is particularly relevant in transition economies since they were closed off from the rest of the world and there is usually a high degree of uncertainty about the quality of the firms being privatized.

Third, sequencing may occur because of political opposition to dramatic reforms (the case in Bulgaria, Poland, Romania, and Slovakia), and it may even increase the feasibility of future reforms (Dewatripont and Roland, 1995). ${ }^{1}$ Fourth, instantaneous privatization may lead to costly unemployment and hence the optimal privatization path may be gradual (Aghion and Blanchard, 1994; Katz and Owen, 1993).

Given that governments are likely to privatize sequentially, the question arises as to which firms they will choose to privatize first. To address this issue, we describe several theories that encompass different possible government objectives. The theories yield different predictions about the government's sequencing strategy. Since the governments in transition economies usually pursued several goals simultaneously (see e.g., World Bank, 1996), we do not assume that the government had a single objective. Rather, we allow for the fact that the government could have several objectives and ask which one(s) received considerable weight. ${ }^{2}$

We then examine these predictions using data on the population of manufacturing firms sold in the first two waves of the Czech large-scale privatization program. We start by looking at the decision of a government maximizing Pareto efficiency. It is generally argued that the least efficient or profitable firms are the best candidates for privatization from an efficiency perspective since they have the greatest need for restructuring. For example, Frydman et al. (1999) and Claessens et al. (1997) find that efficiency improvements are greatest in firms with lower initial levels of efficiency. Hence, the economic model of a government guided by the principle of increasing Pareto efficiency predicts that the government will privatize the least efficient firms first. ${ }^{3}$ Second, if the privatization procedure involves transferring equity shares to citizens, the government is likely to privatize the best (most profitable) firms first so that the shares transferred to citizens are valuable, thereby building political support for the government.

\footnotetext{
${ }^{1}$ See Roland (2000) for a recent survey of the literature on sequencing of reforms.

${ }^{2}$ The multiple objectives may be nested in an overall objective function (see Section 2.6 below).

${ }^{3}$ As discussed in the following section, this argument assumes that the transaction costs associated with privatizing loss-making firms are not so negative as to outweigh the efficiency gains of privatizing such firms.
} 
Third, privatizing the most efficient and profitable firms first may also be optimal if the government is concerned about the political cost of unemployment since these firms are likely to lay off fewer workers than the inefficient and loss-making firms. A related hypothesis concerning political costs is that the government is less likely to privatize firms in industries that already have employment difficulties. Fourth, when the benefit from privatization is informational in the sense that private firms use and process information more efficiently than government-owned firms, the government may sequence privatization to maximize the flow of information in the economy. In this context Glaeser and Scheinkman (1996), hereafter GS, argue that privatization should begin in those sectors and parts of the supply chain (i) where there is the most uncertainty and (ii) that transmit the most information to other sectors. ${ }^{4}$ Finally, the government may want to maximize sale revenues. To do so, the government may temporarily keep monopolies intact when selling them to get a higher price. (This was the case with fixed-line telephone companies in a number of Central and East European countries.) However, as GS point out, selling monopolies first can decrease economic efficiency. Finally, in the presence of asymmetric information, we show that the government will sell the most profitable firms first if its objective is to maximize revenues from the sale.

From the published surveys of the privatization literature (Megginson, 2005; Megginson and Netter, 2001; Djankov and Murrell, 2002), it appears that the majority of studies have found a positive link between privatization and firm performance. Our results suggest that studies that treat the sequencing of privatization as random are likely to overstate the positive effect of privatization on performance. The most recent survey of privatization in transition economies (Estrin et al., 2007) evaluates studies that measure the effects of privatization by their methodology and strongly supports our point.

This is the first study to investigate firm characteristics that are likely to determine the sequencing of privatization. In a recent book that extensively surveys the privatization literature, Megginson (2005) mentions two other studies that empirically examine sequencing in privatization. Specifically, Perotti and Guney (1993) show that state holdings are sold gradually in order to build confidence among investors, and Dyck (1997) shows that East Germany's privatization program was subject to few political constraints and that companies were speedily sold to the highest bidders. None of the studies mentioned show that better firms are sold first, or indeed any of the other results of our paper (Megginson, 2005, pp. 74-75).

By identifying the nature of sequencing of privatization, our analysis contributes to a better understanding of the behavior of governments and firms. Further, the objectives and issues we consider are relevant for the transition economies as well as East Asian, South Asian, African, and Latin American economies that still have sizable state sectors and are pursuing privatization.

Using data on the population of large- and medium-sized manufacturing firms privatized in two successive waves in the Czech Republic (a model economy that started the transition almost completely state-owned), we investigate the priorities of the government. We find strong evidence that the Czech government privatized more profitable firms, and firms with large market shares, first. This outcome is consistent with

\footnotetext{
${ }^{4}$ Many firms in the transition economies faced substantial uncertainty because of the collapse of product and input markets after the break-up of the Council for Mutual Economic Assistance (CMEA), the common trading area of the Soviet bloc.
} 
the government placing priority on maximizing privatization revenues and public goodwill. It is also consistent with minimizing political costs, but our data do not support the secondary hypothesis of this model that industry labor market conditions were an important determinant of privatization.

Our results also allow us to rule out the hypothesis that improving Pareto efficiency was a key objective of the government. Finally, our results contradict the prediction of the GS model that firms with market power should be privatized later, when competitive conditions and adequate regulatory institutions have been established. However, we find that the privatization process was consistent with the other recommendation of the GS model, namely that privatization should start where demand or cost volatility is the greatest and where it maximizes the flow of information. In particular, we find that firms likely to be more responsive to changes in demand conditions were privatized first.

Our paper is organized in four additional sections: In Section 2 we describe five models of government priorities that would lead to particular sequencing strategies in privatization. In Section 3 we describe the institutional framework of the large-scale privatization program in the Czech Republic. ${ }^{5}$ In Section 4 we use firm-level data from the Czech Republic to test the predictions of the theoretical models. Section 5 concludes the paper.

\section{The government's objectives in privatization}

In privatization programs across the world, governments have chosen to privatize firms sequentially rather than all at once. The governments are likely to sequence the privatization of firms because of the high costs associated with selling all firms at once. These costs may be divided into (i) congestion costs, assumed to be common to all firms and increasing with the number of firms to be privatized and (ii) transaction costs that vary with firm characteristics such as performance. Congestion costs relate to the capacity of the government bureaucracy to process large amounts of information and decisions, and they dictate that in mass privatizations the government will not privatize all the firms at once. The transaction costs will affect the decision to privatize some firms before others. ${ }^{6}$ Under standard assumptions the government will first privatize firms with the highest net benefits (gross benefits minus transaction costs), and will privatize firms until the marginal benefit of privatizing one more firm is less than the marginal congestion costs in that period.

Our discussions with policy makers indicate that transaction costs were relatively limited and consisted mainly of (i) the costs of acquiring information about the firms and conducting the sale, and (ii) the restructuring costs of preparing firms for privatization. The Czech government for instance spent little on preparing firms for sale, leaving restructuring to the new owners. The transaction costs of acquiring information is also reported to have been limited as the Communist accounting system enforced uniform data collection and reporting requirements for all firms, irrespective of performance. Moreover, the managers of each SOE were required to prepare a privatization proposal providing the

\footnotetext{
${ }^{5}$ The large-scale privatization program privatized virtually all medium- and large-size firms in the Czech Republic. The program had several components, including distribution of shares to citizens at large and direct as well as sealed bid sales to foreign and domestic investors.

${ }^{6}$ Transaction costs may also vary across the different privatization waves. If they decrease over time, for example, this may affect the number of firms sold in each wave. However, it will not affect the impacts of the independent variables on the index function for privatization that we estimate below.
} 
firm's current and past balance sheets and income statements. This information was made available to all prospective bidders who were in fact required to attach it to their bids (see Kotrba, 1995, p. 167). ${ }^{7}$ Further, the government was well informed about the market performance of all firms since financial performance prior to privatization already reflected the effects of price and trade liberalization, and the government also knew the extent of subsidies it provided to each firm. Hence, these information costs of privatization were limited and unlikely to be highly correlated with firm performance.

One may argue that the government has to spend more time establishing the value of a poorly rather than a well performing firm. This would make transaction costs negatively correlated with firm performance before privatization. However, institutional and empirical evidence also suggests that international investors usually went after the better firms (Sabirianova et al., 2005) and used expensive lawyers and consultants in preparing the bids and executing the negotiations. In many of these cases the government also contracted with expensive international business consultants. On the other hand, the government tended to rely on local (less expensive) expertise in the case of bids by domestic investors for "less valuable" firms. This component of transaction costs is likely to be positively correlated with firm performance. The same positively and negatively correlated categories of transaction costs apply to the acquisition of information by the buyers. ${ }^{8}$ Since there are no reliable data on the relative magnitudes of these components, we proceed with the premise that transaction costs may be weakly correlated with firm performance and that this correlation may be positive or negative.

In the subsections below we develop predictions arising out of the different objectives that the government may pursue in the privatization process.

\subsection{Maximizing Pareto efficiency}

In this section we investigate the sequencing decision of a government concerned with increasing economic efficiency through privatization. We note that efficiency considerations may also dictate shutting down unviable firms. Indeed, prior to the start of the privatization program, the Czech government liquidated some firms that were found to be unviable (Hashi et al., 1997).

Assuming that privatization will improve the efficiency of firms, and that congestion costs dictate that firms will not be sold all at once, will a government concerned with efficiency maximization sell more or less efficient firms first? Investigating the effect of privatization on firm performance in transition economies, Claessens et al. (1997) and Frydman et al. (1999) find that the most inefficient firms experience the greatest improvement in efficiency. This suggests that a government concerned with maximizing efficiency should privatize the least efficient firms first. ${ }^{9}$

In our empirical work we look at two proxies for efficiency: (i) Profitability and (ii) the disparity between labor's marginal product and wage. Regarding the first, in their study of the effects of privatization Frydman et al. (1999) show that firms with higher initial levels of production costs experience the greatest reduction in costs, which suggests that

\footnotetext{
${ }^{7}$ Since all firms behaved this way, the cost to firms of providing this information is not relevant to the decision of which firms to privatize first.

${ }^{8}$ Buyers' costs also will be relevant whenever the government is concerned with efficiency.

${ }^{9}$ This assumes that transaction costs are not too negatively correlated with firm performance.
} 
profitability is likely to increase more for less profitable firms. While profitable firms may also be inefficient, the least profitable or loss-making firms are likely to be the most in need of efficiency enhancing investments (Kikeri et al., 1992). Put another way, since unprofitable firms are likely to be the furthest from the efficiency frontier for their industry, it is reasonable to argue that they are likely to benefit the most from private ownership. For example, in India the government has ruled out the privatization of profitable firms because they claim that there are no efficiency considerations for doing so. Moreover, unprofitable firms that are not shut down require government subsidies to keep them afloat, leading to a misallocation of scarce public resources that could be used for growth enhancing programs such as infrastructure investment. Thus, the prediction with respect to the profitability measure is that a government concerned with maximizing efficiency should privatize more loss-making firms first.

With respect to the second measure of efficiency, the government should first privatize firms in which wages greatly exceed the marginal product of labor. In our data set, we observe the average rather than marginal product of labor for each firm. However, since the two productivities are positively correlated, and are proportional to one another in production functions such as Cobb-Douglas, we use the difference between the average product of labor and the average wage in each firm as an alternative proxy for firm inefficiency. ${ }^{10}$

\subsection{Maximizing public goodwill}

In many transition economies, shares of firms were transferred at a highly subsidized rate to citizens. For instance, the Czech Republic, Kazakhstan, Lithuania, Russia, Slovakia, Slovenia, and Ukraine used the voucher privatization method to transfer shares. Privatization through vouchers helped alleviate public concerns that privatization enriches only a few individuals and generated public support for the government and its current and future reforms. ${ }^{11}$ Moreover, in the 1990s the average tenure of the governments in most Central European countries was about 2 years; hence, governments were likely to be quite sensitive to sequencing privatization in such a way as to maximize voter goodwill.

As mentioned above, congestion costs dictate that in large privatizations the government will sequence the sale of firms. It is reasonable to argue that the public will value profitable firms more, so a government interested in maximizing public support for the reforms is likely to privatize the more profitable firms first.

\subsection{Minimizing political costs}

Governments are likely to be acutely aware of the political costs of layoffs that will accompany privatization. It follows that the government will prefer to privatize first those SOEs that are likely to shed the fewest workers. If political costs depend only on layoffs in

\footnotetext{
${ }^{10}$ Ideally we would like measures of profitability under capitalism and measures of externality costs, such as pollution, that the firm produces.

${ }^{11}$ The launching of privatization in most transition economies was typically accompanied by a public relations campaign to generate goodwill for the government. For example, in the Czech Republic each voucher book displayed the signature of the Prime Minister, indicating clearly to whom the citizens should be grateful for their newly acquired wealth.
} 
the privatized firms, the government should privatize the more profitable and efficient firms first since these firms are likely to have less surplus employment.

We also investigate whether firms in declining industries facing low employment growth are likely to be privatized later. This latter prediction potentially allows us to distinguish between the political cost model and the models of public goodwill and revenue maximization discussed in this section. ${ }^{12}$

In our data, we test whether the more profitable firms, firms in which the difference between the average product of labor (proxying for labor's marginal product) and the wage is higher, and firms in low employment growth industries are more likely to be privatized first.

\subsection{Maximizing efficiency due to informational gains}

GS have been the only authors to theoretically address sequencing, and their paper examines sequencing strategies that would increase the efficiency of SOEs. They argue that a primary advantage of private ownership is that it enhances efficiency by improving firms' acquisition of, and responsiveness to, information about demand shocks and input costs. The basic assumption of their model is that private firms respond to demand and cost shocks, but this information is unobserved or ignored by SOEs. ${ }^{13}$ Specifically, SOEs produce a fixed level of output based on the expected values of demand and cost, while private owners observe the actual values and adjust their production when demand and cost conditions change. This assumption is justified in centralized or planned economies where government bureaucrats who lack the incentive to invest in industry-specific information are involved in the production decisions of SOEs. Even if SOE managers are equally well informed as the private sector, these managers are required to pursue objectives in addition to profit maximization, such as fulfilling output and employment quotas, which would reduce their flexibility to respond to market shocks. GS argue that given political interference, soft budget constraints, weak managerial incentives for gathering information, and the absence of stock market monitoring of SOEs, only privatization would allow these firms to make profit-maximizing decisions in response to fluctuations in market conditions.

Hence, if the government is concerned about increasing efficiency in the sense of improving the responsiveness of SOEs to fluctuations in market conditions, the GS model predicts that privatization should begin where demand or cost volatility is the greatest and where it maximizes the flow of information.

In the GS model there are three sectors: Upstream, downstream and retail. In our analysis, we test two predictions of the model pertaining to the sequencing of privatization across industries. First, GS argue that when demand uncertainty is greater than cost uncertainty, downstream industries should be privatized before upstream industries, because downstream industries are better positioned to transmit information between the retail and upstream sectors. When the retail sector is private, GS show that privatizing

\footnotetext{
${ }^{12}$ While we would like to include unemployment in the region where the firm is located as a proxy for the government's sensitivity to the political cost of unemployment, we do not observe the locations of the firms' plants.

${ }^{13}$ SOEs may be less responsive because in centrally planned regimes these firms fulfill a production plan that is not necessarily consistent with market conditions. However, it is not necessary to assume that they ignore these shocks as long as private firms observe these shocks with greater accuracy.
} 
downstream firms should occur before upstream privatization so that the flow of information between the private upstream and the private retail sectors is not disrupted by the intermediate state-owned downstream sector.

Second, GS argue that industries experiencing the highest demand or cost volatility should be privatized first, since firms in these industries need to respond to changing market conditions and hence are likely to benefit the most from privatization. Many transition economies faced a collapse in product markets due to the break-up of the Sovietera trading system. Since demand fluctuations were the main source of volatility in these economies, GS's model predicts that industries which were most affected by the collapse of the Soviet common market should be privatized first. GS also note that the informational gains from privatization may be offset by a loss of consumer surplus if firms with significant market power are privatized and allowed to engage in monopoly pricing.

The GS model provides a different set of predictions than have been obtained in the previous models. In the empirical section we test whether downstream industries and industries that faced the greatest demand shocks were privatized first. We also test if the market share of a firm affects the probability of it being privatized early. If the government maximizes public goodwill or privatization revenues (Section 2.5), firms with high market share should be privatized first since this variable may also act as a proxy for profitability. ${ }^{14}$ Thus, the market share variable also allows us to compare the relative priority placed on revenue and public goodwill vs. efficiency.

\subsection{Maximizing revenues in the presence of asymmetric information}

In the Czech Republic, the government raised $\$ 8$ billion in privatization revenues (World Bank, 1999). In this section we therefore consider a model where one of the government's objectives in terms of the framework of Section 2 is to maximize privatization revenues in the presence of asymmetric information between the government and prospective investors about the potential value of the firms. Firms chosen for privatization may have characteristics that are unobservable to buyers, but are correlated with the value or profitability of the firms. ${ }^{15}$ Given this objective, the question then arises as to whether the government should privatize the better or worse firms first.

We assume that the government knows the long-term profitability of the firm, but buyers do not.This may be justified on the basis that not much was known about these firms by outsiders prior to the collapse of the Soviet bloc. It is also consistent with Perotti (1995), who assumes that buyers are less informed than the government because of uncertainty regarding future policies that may affect the value of firms.

\footnotetext{
${ }^{14}$ Unfortunately we only observe market share at the two-digit industry level, while it would be preferable to have market share at the three-digit level. If one made the simplifying assumption that each firm's two-digit share is a constant fraction of its three-digit share, the market share coefficient will be biased upwards (since the independent variable is biased downward) but elasticities based on this coefficient and the test statistic for it will not be affected. If, as one would expect, each firm's three-digit market share is not a constant multiple of the twodigit share, we will also have an errors in variables problem. This will tend to bias the coefficient towards zero (abstracting from the scale effect) and elasticities and test statistics will now be biased toward zero overall, making it harder to reject the null hypothesis that the coefficient is zero.

${ }^{15}$ In a complementary paper, this problem is examined using an auction framework by Chakraborty et al. (2006).
} 
We use a two-period setting with two firms, A and B, many buyers, and one seller. The firms' long-term profits are given by $\theta_{\mathrm{A}, \mathrm{B}} \in \Theta=\{\underline{\theta}, \bar{\theta}\}$, and $\theta$ can take on either of the two values with $\bar{\theta}>\underline{\theta}$. The two firms can be of the same type or of different types; the type of the firm is denoted by its profit. We assume that all the buyers observe public information about the average profitability of the firms. To simplify issues, we assume that different groups of buyers bid in each period, although second period buyers observe the quality of the first period firm. Since there is uncertainty about firm type, the value of the firm to all buyers is given by the expected profits of the firm.

The timing of the game is as follows: The types (profits) $\theta_{i}$ of the firms are assigned by nature, the government observes the types and picks firm A or firm B to be sold in the first period, and the firm is sold at a price equal to its expected value. In the second period, buyers observe the type of the first firm and then bid for the second firm.

To simplify notation, let A be the firm being sold in the first period and B be the firm sold second. We specify the following probability distribution for the firms' profits:

$$
p\left(\theta_{\mathrm{A}}=\bar{\theta}, \theta_{\mathrm{B}}=\bar{\theta}\right)=p\left(\theta_{\mathrm{A}}=\underline{\theta}, \theta_{\mathrm{B}}=\underline{\theta}\right)=\alpha
$$

and

$$
p\left(\theta_{\mathrm{A}}=\bar{\theta}, \theta_{\mathrm{B}}=\underline{\theta}\right)=p\left(\theta_{\mathrm{A}}=\underline{\theta}, \theta_{\mathrm{B}}=\bar{\theta}\right)=\beta,
$$

where $\alpha, \beta \in(0,1)$ and $2(\alpha+\beta)=1$.

Next we calculate the prices offered for each firm under the two sets of buyer beliefs about the government's sequencing strategy.

(a) Buyers believe that the government will sell the better firm first.

The probability that the first firm will be of high value, given that buyers' believe that the government will sell the better firm first, is given by $\alpha+2 \beta$. The price offered for the firm sold in the first period, $p_{1}$, is the expected value of the firm given these buyer beliefs and is equal to

$$
p_{1}=E\left(\theta_{\mathrm{A}} \mid \theta_{\mathrm{A}} \geqslant \theta_{\mathrm{B}}\right)=p_{1}=\bar{\theta}(\alpha+2 \beta)+\underline{\theta} \alpha .
$$

Given that buyers think the seller will sell the better firm first, buyers believe that the first firm is of low value if and only if both the firms are of low value.

In the second period, buyers observe the quality of the first firm. Correspondingly, the price $p_{2}$ for the second firm, conditional on the value of the first firm, is given by

$$
p_{2}= \begin{cases}\frac{\bar{\theta} \alpha+2 \beta \underline{\theta}}{\alpha+2 \beta} & \text { if the buyer observes } \theta_{A}=\bar{\theta}, \\ \underline{\theta} & \text { if the buyer observes } \theta_{A}=\underline{\theta} .\end{cases}
$$

When the second period buyers observe a high value firm first, conditional on their beliefs that the better firm is sold first, they believe that the probability of the second firm being high value as well equals $\alpha$, while the probability of the second firm being low value equals $2 \beta$. However, if they observe that the first firm is of low value, given that they expect the government to sell the best firm first, they will conclude that the second firm must be low value as well. Using Eqs. (1) and (2) it is straightforward to show that the payoff from selling the good firm first is greater than the payoff from deviating. Hence, when the buyers believe that the better firm will be sold first, it is an equilibrium strategy for the government to lead with the best firm. To see the intuition, suppose that the buyers believe that the government will lead with the better firm, but the government deviates and sells the worse 
firm first. Hence, buyers in the second period will observe the low quality of the first firm and conclude that the second firm is of equal or lower quality. As a result, the second period price will be lower than if the government had kept to the strategy of selling the better firm first.

(b) Buyers believe that the government will sell the worse firm first.

As in the previous case, the first period price is the expected value of the firm given buyers' beliefs and is equal to

$$
E\left(\theta_{\mathrm{A}} \mid \theta_{\mathrm{A}} \leqslant \theta_{\mathrm{B}}\right)=\bar{\theta} \alpha+(\alpha+2 \beta) \underline{\theta} .
$$

The second period price depends on the realization of $\theta_{\mathrm{A}}$ (the observed value of the first period firm) and is given by

$$
p_{2}= \begin{cases}\bar{\theta} & \text { if the buyer observes } \theta_{\mathrm{A}}=\bar{\theta}, \\ \frac{2 \beta \bar{\theta}+\alpha \underline{\theta}}{\alpha+2 \beta} & \text { if the buyer observes } \theta_{\mathrm{A}}=\underline{\theta} .\end{cases}
$$

It follows from Eqs. (3) and (4) that the payoff from deviating is higher than the payoff from following, and the government will always choose to deviate when the buyers believe that it will sell the worst firm first. Therefore, it cannot be equilibrium for the buyers to believe that the government will sell the worst firm first. To see this, suppose that buyers believe that the government will lead with the worst firm, and instead the government deviates and sells the better firm first. In this case, second period buyers observe the high quality of the first firm, and given their beliefs about the government's strategy, they conclude that the second firm is of equal quality. Thus, second period buyers pay a higher price than they would if the government had sold the worse firm first. The pure strategy equilibrium in this model is for the government to lead with the more profitable firm. ${ }^{16}$

This general question of whether the best or worst good should be sold first arises whenever a seller has some private information about the quality of the goods and is concerned about the effect of previous sales on buyer expectations. The model described above shows that first impressions matter, leading to a best foot forward strategy in equilibrium.

In the majority of privatizations, governments often retain an ownership stake in the firms. For example, the Czech government held on to some shares of the companies privatized in the first round for the explicit purpose of selling the shares later. The equilibrium results do not change if the model is generalized to the case where the government retains an ownership stake in the firms. It can also be shown that under reasonable parameter values, a best foot forward strategy is the unique pure strategy equilibrium if, in the first period, the government retains the profits from the firm it does not sell.

In the empirical section, we test this model by investigating whether more profitable firms are sold in the first wave of privatization. Specifically, we use the difference between firm output and the wage bill, the difference between the value of the average product of labor and the wage, firm market share, and firm (accounting) profits as measures of firm profitability.

\footnotetext{
${ }^{16}$ This assumes that transaction costs are not too positively correlated with firm performance.
} 


\subsection{Government's multiobjective function}

In this section we show how government may take multiple objectives into account and how this translates into our empirical framework. Let $U_{\mathrm{R}}$ be the Von Neumann-Morgenstern utility that the government derives from privatization revenue, $U_{\mathrm{g}}$ be its utility from the goodwill that it obtains from the population at large, $U_{\mathrm{E}}$ be the utility it derives from improving efficiency, and $U_{\mathrm{C}}$ be the utility it obtains from avoiding political costs. Following Svejnar (1982, 1986), one can view government decision-making as reflecting the following overall objective function

$$
U=U_{\mathrm{R}}^{\gamma_{\mathrm{R}}} U_{\mathrm{E}}^{\gamma_{\mathrm{E}}} U_{\mathrm{G}}^{\gamma_{\mathrm{G}}} U_{\mathrm{C}}^{\gamma_{\mathrm{C}}},
$$

where each $\gamma_{i} \geqslant 0$ is the weight that the government places on objective $i$. The objective function nests as special cases situations where the government has only one objective. For instance, when the government has revenue maximization as its sole objective, $\gamma_{\mathrm{E}}=\gamma_{\mathrm{G}}=\gamma_{\mathrm{C}}=0$ and $U=U_{\mathrm{R}} \cdot{ }^{17}$

To see how the government will choose firms to be privatized in this framework, suppose the government replaces a candidate firm to be privatized by a more profitable one. This substitution will decrease utility from increasing efficiency, while it will increase utility from higher revenues and public goodwill, and lower political costs. Thus, if the government chooses to privatize the more profitable firms first, this does not imply that the government puts zero weight on increasing efficiency. Instead, the increase in utility from the efficiency gains of privatizing unprofitable firms is outweighed by the gains from privatizing the more profitable firms first. ${ }^{18}$

\section{The Czech privatization program}

In January 1990 the Czech Republic, as part of the former Czechoslovakia, started its transition to a market economy from a position of virtually total state ownership. In 1989 only $1.2 \%$ of the labor force and $2 \%$ of all registered assets belonged to the private sector, and in 1990 only $4 \%$ of the gross domestic product was attributed to the private sector (Dyba and Svejnar, 1995). Yet, by the end of 1995, about 75\% of all assets had been privatized as a result of three main initiatives.

First, between 1990 and 1991, shops, restaurants, housing, and other properties valued between $\$ 2.5$ billion and $\$ 4.2$ billion were restituted to previous owners. Second, between 1991 and 1993, small firms in retail trade, catering, and other services were privatized in a $\$ 1$ billion small-scale privatization program, mostly through auctions. Third, the method by which most medium and large SOEs were privatized was the large-scale privatization program, accounting for about $\$ 30$ billion in asset value (Dyba and Svejnar, 1995). ${ }^{19} \mathrm{We}$ analyze the large-scale privatization program.

\footnotetext{
${ }^{17}$ Note that if the weight on efficiency or revenue is positive, then transaction costs will be relevant for the privatization decision.

${ }^{18} \mathrm{We}$ are grateful to one of the referees for asking us to clarify this point.

${ }^{19}$ Kotrba (1995) states that the total book value of capital in the Czech Republic in 1990 was equal to 2604 billion Czech crowns and the book value of firms privatized under the large-scale program was more than $50 \%$ of this amount (p. 164). The total book value of joint stock companies was over $86 \%$ of the total book value of firms privatized in the large-scale program (Table 8.5, p. 166). The firms in our regression sample are these joint stock companies.
} 
In order to handle the large number of firms, the large-scale privatization program was divided into two waves and a variety of methods were employed, reflecting several goals proclaimed by the government-speed, fairness, revenue maximization, and public support. In particular, for most firms the government allocated some shares into the voucher scheme for support, speed, and fairness. It sold directly or through sealed bids the other shares and in this process the price (and hence revenue) was usually the main criterion for picking a given bid given that a firm had been chosen for privatization.

Within each category of shares, sequencing was an issue and transactions were carried out over time. Reflecting this strategy, firms were allocated by the government for privatization in the first wave at the end of April 1992 and shares were made available to new owners at the end of May 1993. In the second wave, the privatization projects were approved at the end of 1993 and shares were made available to new owners toward the end of 1995. The approximately 2-year interval between the two waves is consistent with our model of sequencing in Section 2.

As mentioned above, the large-scale privatization program employed several privatization methods. The most common was a transformation of firms into joint stock companies and the subsequent privatization of their shares. Joint stock firms accounted for about $77 \%$ of the privatization revenues received by the Czech government. ${ }^{20}$ About 350 firms were sold for cash in the large-scale privatization program, raising about $\$ 8$ billion in privatization revenues (World Bank, 1999). In terms of share value, $20 \%$ to $30 \%$ of all the shares of joint stock companies were sold to foreign and domestic buyers for cash through direct sales, tenders, or financial intermediaries (World Bank, 1999). The revenues from these sales went directly to the government and our focus on revenue maximization as a government objective is consistent with this institutional feature. In some firms, a fraction of shares was sold for cash, and another fraction was distributed through a voucher privatization scheme. According Mejstrik et al. (1997, p. 61), voucher privatization accounted for $37 \%$ of the total book value of state-owned assets.

The government also retained shares averaging $20-25 \%$ of the share value being privatized. Some of these shares were used to meet restitution claims, while the rest were sold subsequently in the secondary market or to strategic investors (Mejstrik et al., 1997; World Bank, 1999). Information on the percentage of shares of each firm sold through the various channels is not publicly available. However, we observe information on which firms were privatized in the first wave and which were left for later. In our empirical work we use this information to analyze the sequencing of privatization.

The voucher privatization scheme was an important component of each wave of the large-scale privatization program. Under this scheme, every Czech citizen over 18 could buy a book of vouchers containing 1000 investment points for a nominal fee of $\$ 34$. Citizens could use these voucher points to bid directly for shares, or they could transfer the points to investment privatization funds (IPFs) that bid for shares on their behalf. Although the government did not receive revenues from the shares distributed through vouchers, voucher privatization helped create widespread support for the reforms. Thus, focus on public goodwill as a government objective is relevant for the Czech Republic (and the other economies that used a voucher scheme). The fact that the government privatized

\footnotetext{
${ }^{20}$ Examples of joint stock companies in our data that were sold for cash include Skoda (automobile) sold to Volkswagen, Tabak Kutna Hora (tobacco) sold to Philip Morris, and Cokoladovny (chocolate) sold to Nestle.
} 
by simultaneously selling shares and distributing them to the public through the voucher program suggests that the government had multiple objectives.

In the first wave, nearly two-thirds of the participating public invested their vouchers in nearly 450 IPFs, with the 14 largest IPFs collecting over $78 \%$ of the voucher points remitted to the funds (World Bank, 1999). Many of the largest funds were created and operated by local banks that temporarily remained majority state-owned. ${ }^{21}$ The control of the largest IPFs by majority state-owned banks was an unexpected outcome for the Czech government since it, unlike the Polish government, left the creation of IPFs to market forces. ${ }^{22}$ There is every indication that the government expected voucher privatization to constitute a legitimate transfer of ownership to private owners (World Bank, 1999).

\section{Data, specification, and empirical results}

\subsection{Data}

We use a large data set of firms sold in the Czech large-scale privatization program. The data have several notable advantages. First, they capture the important large-scale privatization program that was clearly divided into two non-overlapping waves. Second, they cover the population of medium and large industrial firms rather than a smaller (possibly non-random) sub-sample. Third, the data permit a clear identification of which firms were privatized early and which ones later. Fourth, the Czech data are of relatively good quality - a feature that is important since it is often difficult to obtain dependable firm-level data in transition economies.

Our original data set contains quarterly and annual observations, starting in 1992, on the population of all industrial firms with 25 or more workers, or approximately 2500 firms. ${ }^{23}$ The data were reported by firms to the Czech Statistical Office and contain information from balance sheets and profit and loss statements. The reported variables include sales, production, employment, average wages, total wage expenditures, accounting profits, and two-digit industry classification. Regional identification is not available.

From this data set we exclude approximately 750 firms that were either restituted to previous owners or privatized in the small-scale privatization program. Restitutions could be claimed during a period of several years, and the government allowed considerable latitude for the prior owners to submit their claims. Unlike the large-scale program, there was no explicit sequencing in the small-scale privatization effort. Small-scale privatization

\footnotetext{
${ }^{21}$ Like mutual fund companies in the United States, IPFs in the Czech Republic were expected to diversify risk for individual investors by investing in many firms. Fund involvement resulted in potentially concentrated control over managers, but some have argued that the conflict of interest resulting from bank-owned funds owning firms that were indebted to these banks prevented meaningful restructuring. It was not until after the recession of 1997 that the government began to address these issues and undertook banking sector reforms. The last remaining state-owned bank, Komercni Banka, was privatized to French Societe Generale in 2001.

${ }^{22}$ However, the government passed a law prohibiting investment funds from gaining a majority stake in any firm: a fund could not own more than $20 \%$ of the shares of a single firm, nor could funds established by the same founder buy more than $20 \%$ of the same firm.

${ }^{23}$ Since we are dealing with the population of large- and medium-size firms in a given country, one may think of statistical inference as reflecting a draw from the universe of possible economies undergoing large-scale privatization in central and Eastern Europe. Alternatively, to justify the use of standard errors one can turn to the concept of 'Super-populations' used in survey research, see, e.g. Hartley and Sielken (1975).
} 
was a continuous process, and its timing reflected the diverse capabilities of local government units more than sequencing. The small-scale firms are also not comparable to the firms privatized in the two waves of the large-scale program because they have significantly smaller asset size, employment, and output. ${ }^{24}$ Since $\$ 30$ billion worth of assets were privatized in the large-scale program, compared with $\$ 1$ billion in the small-scale program, by focusing on the former program we are analyzing the privatization of the bulk of the property in the Czech Republic.

We also exclude about 250 cooperatives and 37 electric and water utility companies. The cooperatives account for $1.8 \%$ of total output and $3 \%$ of the total wage bill of the sample of 2500 firms. Cooperatives were not privatized in the large-scale privatization. Electric and water utilities were considered strategic and retained under state ownership at this stage of the privatization process. The excluded utility companies account for $0.6 \%$ of total output and $1.5 \%$ of the total wage bill of the total sample. These exclusions yield data on 1470 firms that went through the large-scale privatization program. For the purposes of our analysis, we need annual and first quarter 1992 values for sales, value of output, average wages, labor force, accounting profits, and industry classification for each firm. After deleting firms with missing values, we obtain our group of 1121 firms. Note that these firms account for over $78 \%$ of sales and $73 \%$ of the wage bill of the total sample. Of these firms, 664 were privatized in the first wave of the large-scale privatization process and 457 were privatized in the second wave.

In comparison, published studies of the effect of privatization on firm behavior in transition economies tend to use survey data on relatively small samples of firms. For example: Frydman et al. (1999) use a sample of about 200 firms; Barberis et al. (1996) use a similar size sample in their study of Russian shops; Bilsen and Konings (1998) use survey data on about 400 firms divided among Bulgaria, Romania, and Hungary; Grosfeld and Nivet (1997) use a sample of 173 of the largest 500 companies in Poland; and Claessens and Djankov (1999) use data on approximately 700 manufacturing firms from the Czech Republic.

\subsection{Empirical specification}

In Section 2, we consider alternative government objectives that may determine the sequencing of firms for privatization. Of course, the government may care about several or all of these objectives. As we show in Section 2.6, we can think of the government as having a weighting function over the objectives or over the observable variables that reflect or capture these objectives. Alternatively, government decisions may be viewed as the result of bargaining between competing groups, and the overall objective function weighs the utility of competing groups. The weights would depend on the bargaining power of the individual groups (Svejnar, 1982; Prasnikar et al., 1994). The probit equations that we estimate below may be interpreted as estimating such a weighting function over the observable variables.

We estimate probit equations where the dependent variable is coded one if a firm is privatized in the first wave and zero if it is privatized in the second wave. We choose our explanatory variables to test the predictions of alternative government objectives,

\footnotetext{
${ }^{24}$ The value of output for the small-scale firms is on average one-fifth that of the joint stock companies in the data.
} 
Table 1

Theoretical predictions of models of privatization

\begin{tabular}{|c|c|c|c|}
\hline Theory & Variable $^{\mathrm{a}}$ & Definition & Sign \\
\hline \multirow[t]{4}{*}{ (1) Maximizing Pareto efficiency } & $(Q / L-W / L)_{i}$ & Value of average product-average wage & - \\
\hline & $(Q-W)_{i}$ & Value of output-total wage bill & - \\
\hline & $P_{R O F I T}$ & Accounting profit & - \\
\hline & $M K S H A R E_{i}$ & Market share & - \\
\hline \multirow[t]{4}{*}{ (2) Maximizing public goodwill } & $(Q / L-W / L)_{i}$ & & + \\
\hline & $(Q-W)_{i}$ & & + \\
\hline & $\mathrm{PROFIT}_{i}$ & & + \\
\hline & $M K S H A R E_{i}$ & & + \\
\hline \multirow[t]{4}{*}{ (3) Minimizing political cost } & $(Q / L-W / L)_{i}$ & & + \\
\hline & $(Q-W)_{i}$ & & + \\
\hline & $\mathrm{PROFIT}_{i}$ & & + \\
\hline & $E M P G R$ & $\begin{array}{l}\text { Employment growth rate in industry } \\
\text { between } 1991 \text { and } 1992\end{array}$ & + \\
\hline (4) Maximizing efficiency through & $C M E A$ & Demand shock industry dummy & + \\
\hline \multirow[t]{2}{*}{ informational gains ${ }^{b}$} & $D O W N$ & Downstream industry dummy & + \\
\hline & $M K S H A R E_{i}$ & & - \\
\hline \multirow{4}{*}{$\begin{array}{l}\text { (5) Maximizing privatization } \\
\text { revenues }\end{array}$} & $(Q / L-W / L)_{i}$ & & + \\
\hline & $(Q-W)_{i}$ & & + \\
\hline & $P_{R O F I T}$ & & + \\
\hline & $M K S H A R E_{i}$ & & + \\
\hline
\end{tabular}

${ }^{a}$ An $i$ subscript denotes a firm specific variable.

${ }^{\mathrm{b}}$ This is the Glaeser and Scheinkman (1996) model.

summarized in Table 1. The Pareto efficiency model suggests that the government should sell the least profitable firms first. However, the public goodwill, political cost, and revenue maximization models predict that the government will want to sell the more profitable firms first. To investigate this issue, we use (separately) annual 1992 values of three alternative variables as indicators of profitability: PROFIT (accounting profits); $(Q-W)$ (difference between the value of total output and the total wage bill); and $(Q / L-W / L)$ (difference between the value of average product of labor and the average wage), where $L$ stands for employment. ${ }^{25}$ The profitability variables complement one another. Accounting profits capture all of the input costs but may be subject to reporting error, while $(Q-W)$ and $(Q / L-W / L)$ underestimate total cost (because they ignore other inputs) but allow us to focus directly on the relationship between revenues and labor cost. ${ }^{26}$ We also use an explanatory variable MKSHARE measuring the firm's market share in the industry (ratio of firm sales to industry sales) as a proxy for profitability. ${ }^{27}$ The Pareto efficiency model predicts that all these variables should have negative coefficients while the other models (except Glaeser Scheinkman (GS)) predict that the coefficients should be positive.

\footnotetext{
${ }^{25}$ We include the different measures of profit separately so as to avoid potential multicollinearity problems.

${ }^{26}$ Assets are reported only for a small number of firms in the data and including them would greatly reduce our sample size.

${ }^{27}$ Another variable that may affect performance is the cost of capital post-privatization, which we do not observe. Firms inherited their fixed capital from the communist era and there was little difference in the tax treatment of firms in different regions and industries at this time.
} 
The GS proposition that firms with greater monopoly power should not be privatized early since they offer lower efficiency gains from privatization suggests that MKSHARE should have a negative coefficient. Note that this prediction is consistent with the Pareto efficiency model but not the other models. The GS model has no prediction with regard to firm profitability conditional on market share. We test the GS predictions regarding which industries should be privatized early to reap the informational gains from privatization by creating two dummy variables. The first dummy variable is $C M E A$, which is coded one for industries most affected by the break-up of the Soviet common trading area known as the CMEA and zero otherwise. Analyzing the effect of demand uncertainty is relevant because of what is known as the CMEA shock. The trading system of the Soviet bloc countries began disintegrating in 1990 and was dismantled in 1991, resulting in a collapse of trade. Exports between Central European countries fell 25\% between 1989 and 1990 and were still 13\% lower than the previous year in 1993. The trend is similar for exports between Central European countries and the former Soviet Union. Industries that relied heavily on exports to these markets experienced considerable demand uncertainty after the collapse of the CMEA. To identify industries that faced demand uncertainty following the collapse of the CMEA, we selected industries that experienced declining exports and output after 1991, using evidence from the statistical yearbooks of the Czech Republic and the detailed discussion of this issue in Bohata et al. (1995). The industries included in this category are mining of non-energy materials, mining of metal ores, other mining, textiles, wood products, pulp and paper products, and other non-metallic mineral products. In selecting the CMEA industries, we were conservative and did not include industries, such as production of transportation equipment, that were also somewhat significant exporters and at the same time were becoming technologically obsolete. Had we included these other sectors, we would have captured even greater changes in sales and export/sales ratios. ${ }^{28}$

An important question arises as to whether there was not a fast replacement of the decreasing Czech-CMEA trade by Czech-German trade. ${ }^{29}$ While such a reorientation occurred, it was relatively slow for three reasons. First, there was a different composition of Czech exports to the "hard" markets in the West and the "soft" markets in the East. Czechoslovakia's exports to CMEA resembled a pattern of exports of a developed industrial country (high share of machinery in exports), while its pattern of trade with developed countries (Germany in particular) was more similar to that of a developing country (exporting a high share of fuels and mineral raw materials). In fact, in the very first stage of the transition, Czechoslovakia increased its exports of raw materials to the West and suffered a decline in exports of machinery to the East. The second reason for a relatively slow reorientation was the low initial base of exports to the West. In 1989, the value of Czechoslovak trade with the European Economic Community was equal to only about $18 \%$ of total Czechoslovak exports, while exports to CMEA amounted to $55 \%$ of total exports. Hence, a substantial increase in the volume of trade was necessary to compensate for the loss of CMEA markets. Third, the commodities exported East were

\footnotetext{
${ }^{28}$ Our discussions with managers and policy makers indicate that the Czech Republic (and until the end of 1992 , Czechoslovakia) was a small enough economy that every firm knew the relevant suppliers of inputs and users of output. Unlike in trade with the CMEA and the West, firms did not use the services of state trading firms for domestic purchases and deliveries. The uncertainties hence came primarily from the collapse and final abolishing of the CMEA. Note that the Finnish economy experienced a similar decline to that of the Central European countries on account of its trade decline with the CMEA.

${ }^{29} \mathrm{We}$ are grateful to one of the referees to bringing this point to our attention.
} 
historically of lower quality that those exported to the West. Some Czechoslovak companies therefore exported to CMEA markets because they were not able to sell at Western markets and their reliance on Eastern markets often increased as their production became more obsolete. Simply switching the destination of exports from CMEA to Germany was therefore often not viable. The Skoda automobile producer is a case in point. In the 1980s, Skoda had a reputation for low quality and had to leave some West European markets for non-compliance with environmental regulations. In 1991, it was sold to Volkswagen and only as a result of sizable investments could it return to western markets. In fact, the first model that was competitive on the Western markets was produced only in 1996.

Our second dummy variable, $D O W N$, is coded one for downstream (processed goods) industries and zero otherwise. Following the predictions of GS, the $D O W N$ category includes food, tobacco, textiles, leather, footwear, paper, publishing, electronic machinery and equipment, and transportation. GS show that privatizing downstream will be more efficient than upstream privatization if the retail sector is private. In the Czech Republic, retail and other service-oriented firms were privatized in the small-scale program prior to the start of the large-scale privatization. The GS model suggests that firms in the CMEA and DOWN industries should be privatized first, since these firms are likely to benefit the most from increased responsiveness to information about demand conditions after privatization. In 1991, the CMEA industries had an export/sales ratio of $27.9 \%$, while the non-CMEA industries had an export/sales ratio of $18.2 \%$. Similarly, the DOWN industries had a 1991 export/sales ratio of $24.7 \%$, while the non-DOWN industries had an export/sales ratio of $14.4 \% .^{30}$

Finally, the political cost model predicts that the government will privatize more profitable firms first. It also predicts that the government will privatize firms in industries with strong labor demand first. We use the industry employment growth rate to proxy current labor market conditions in the industry. We expect the coefficient on this variable to be positive (stronger labor demand in an industry lowers the political cost of privatizing firms in that industry). If demand conditions are not important in determining the probability of privatization, this casts doubt on the political costs model and allows one to distinguish it from the public goodwill and revenue maximization objectives. However, we should note that it might be hard to identify the effects of demand conditions on privatization for two reasons. First, we do not have the locations of the firm's plants and thus cannot exploit regional variation in employment. Instead, we use industry-level employment growth. Specifically, we use the difference between 1991 and 1992 industry employment rates, $E M P G R$, since these are not affected by the first wave of large-scale privatization. Second, although employment fell by an average of $11 \%$ between 1991 and

\footnotetext{
${ }^{30}$ We wanted to include a variable for industries facing cost uncertainty, since GS recommend that these firms are good candidates for early privatization, but we could not obtain statistical evidence and the anecdotal evidence was inconsistent. The primary source of uncertainty facing firms in transition economies has been fluctuating demand conditions. Therefore, both the CMEA and DOWN variables capture one of the most significant sources of uncertainty affecting these firms. Between 1991 and 1993, firms in the DOWN industries suffered a $21.6 \%$ decline in production, while firms in the non-DOWN industries experienced a $15.3 \%$ decline. Firms in CMEA and non-CMEA industries faced a $19.7 \%$ and $18.7 \%$ decline, respectively. During the same period, the DOWN and non-DOWN industries experienced a $12.0 \%$ and $58.6 \%$ increase in exports/sales ratio, respectively, while the CMEA and non-CMEA industries experienced a $27.0 \%$ and $29.6 \%$ increase in the export/ sales ratio, respectively. As mentioned above, the $C M E A$ versus non- $C M E A$ differential would be greater if we included in the CMEA category industries such as production of transportation equipment.
} 
1992, there may be insufficient variation in employment growth across industries to precisely estimate the effect of labor market conditions. (The standard deviation of employment growth is $4.1 \%$ in our data.)

We start by estimating the parameters of the following probit equation:

$$
\begin{aligned}
y_{i}^{*}= & \alpha_{0}+\alpha_{1}(Q / L-W / L)_{i}+\alpha_{2} M K S H A R E_{i}+\alpha_{3} C M E A \\
& +\alpha_{4} D O W N+\alpha_{5} E M P G R+u_{i},
\end{aligned}
$$

where $u_{i}$ has a standard normal distribution and $y_{i}^{*}$ is a latent index. A firm is privatized if $y_{i}^{*}$ is greater than zero. To test the sensitivity of our results to the measure used for profits (or the degree of inefficiency), we replace $(Q / L-W / L)_{i}$ with $(Q-W)_{i}$ in Eq. (6) while retaining $M K S H A R E_{i}$ :

$$
\begin{aligned}
y_{i}^{*}= & \beta_{0}+\beta_{1}(Q-W)_{i}+\beta_{2} M K S H A R E_{i}+\beta_{3} C M E A \\
& +\beta_{4} D O W N+\beta_{5} E M P G R+\varepsilon_{i} .
\end{aligned}
$$

Finally, to investigate further the sensitivity of our results to the choice of profit variables, we replace $(Q-W)_{i}$ with accounting profits $P R O F I T_{i}$ and estimate:

$$
\begin{aligned}
y_{i}^{*}= & \gamma_{0}+\gamma_{1} \text { PROFIT }_{i}+\gamma_{2} \text { MKSHARE } \\
& +\gamma_{3} \text { CMEA }+\gamma_{4} \text { DOWN }+\gamma_{5} \text { EMPGR }+v_{i} .
\end{aligned}
$$

Table 1 contains a summary of the predictions of the theoretical models developed in Section 2 and it also lists the variables used to capture these predictions.

\subsection{Econometric issues}

In order to ensure that the explanatory variables capture firm performance before the firms were turned over to new owners starting in the spring of 1993, we use 1992 annual values for the firm-specific independent variables: $(Q / L-W / L)_{i},(Q-W)_{i}, P_{R O F I T_{i}}$ and $M K S H A R E_{i}$ We do not have data prior to the first quarter of 1992. There may be an endogeneity problem for some of the 1992 annual variables if their values were affected by the knowledge of whether the firm would be privatized in the first wave. This information became available at the end of April 1992 and thus the values from May to December 1992 could be affected by whether the firm was chosen for privatization. In principle, the future owners should not have been able to affect the values of these variables since the actual transfer of shares to new owners did not occur until May 1993 or later and existing evidence suggests that little restructuring occurred in the second half of 1992 . However, to allow for the possibility that in practice the annual 1992 variables were affected by the firm's privatization status, we test the null hypothesis for each equation that 1992 variables used in the equation are exogenous. If we reject the exogeneity of a variable, we treat it as endogenous using the 1992 first quarter data as instrumental variables.

To investigate this issue, we test for the endogeneity of the annual 1992 firm-specific values using the test outlined in Rivers and Vuong (1988). Specifically, we estimate first stage equations for each of the annual 1992 firm-specific variables using all of the 1992 first quarter values of the firm-specific variables as instruments. ${ }^{31}$ The model is well identified in

\footnotetext{
${ }^{31}$ Note that this instrument will still be valid if firms knew that privatization was coming, as long as they did not know which firms were more likely to be privatized (in terms of the error in the index function for the firm being privatized).
} 
the sense that the $p$-values for the $F$-test on the excluded explanatory variables in the first stage equations are always below 0.01 . The first stage results are reported in Appendix Table A1. Under the assumption of multivariate normality, we then enter both the respective 1992 annual values and their residuals from the first-stage into the relevant probit equation. We test the null hypothesis that the annual values are exogenous using Wald tests for whether the coefficients on the residuals are significantly different from zero, either individually or jointly. We find that the null hypothesis of exogeneity is rejected only for accounting profits. Thus, when we estimate Eq. (8), we also enter a fitted value for accounting profits and adjust the standard errors to account for this fitted value. ${ }^{32}$

While studies in the transition and development literatures commonly use data reported by firms in balance sheets and income statements, the variable measuring accounting profits may arguably be affected by inappropriate accounting methods. We address this issue by using (as other proxies for profitability) variables such as the difference between total output and the wage bill, the firm's market share, and the difference between the average product of labor and the average wage. ${ }^{33}$ There also may be concerns that our explanatory variables are based on prices from the Communist era and hence are largely irrelevant in predicting firms' performance in a market economy. Fortunately, most prices were liberalized on 1 January 1991, the $20 \%$ temporary import surcharge was eliminated at the end of 1991, and the average import tariff was set at a mere 5\%. Therefore, our 1992 data already reflect world prices in the context of modest inflation. Finally, the question arises as to whether stock market prices could be used to measure profitability. However, these prices report the post-privatization, rather than the pre-privatization, performance of firms and hence cannot be used to predict whether a firm is privatized in the first wave. Moreover, this variable is not even available in 1993 for firms not privatized in the first wave.

\subsection{Empirical results}

In Table 2 we present the mean 1992 values of the explanatory variables. Column 1 contains the values for all firms, while columns 2 and 3 contain the values for firms privatized during the first wave and the second wave, respectively. Column 4 contains the $t$ statistic for the null hypothesis that the mean values in columns 2 and 3 are equal. Note that firms privatized in the first wave are, on average, more likely to be in downstream industries and have higher average values of accounting profits, average product minus average wage, value of output minus wage bill, and market share. These firms are also more likely to have been affected by the collapse of the $C M E A$, but the difference between the first and second wave firms for this variable is not statistically significant. Finally, there is very little difference in mean industrial employment growth between the two types of firms.

Table 3 presents our results for the specifications given by Eqs. (6), (7), and (8). In the first three columns of Table 3, we report our results using annual 1992 values for the firmspecific variables. The reported coefficients provide the marginal effect or the change in the

\footnotetext{
${ }^{32}$ Note that this estimated coefficient implicitly uses a different normalization (such normalizations are inherent in the use of a probit model). As a result, the coefficient obtained by simultaneous equation methods is a lower bound on the true value of the coefficient.

${ }^{33}$ However, one advantage of the accounting profits variable is that it nets out the cost of raw materials and energy.
} 
Table 2

Means of principal variables in 1992 by privatization status of firms

\begin{tabular}{lcccc}
\hline Variable & \multicolumn{1}{l}{ Values for } & & \\
\cline { 2 - 5 } & All firms & Firms privatized in & Firms privatized in & $\begin{array}{l}\text { Normal statistic } \\
H_{0}:(2)=(3) \\
\text { Wave } 2\end{array}$ \\
& 1 & Wave 1 & 3 & 4 \\
\hline CMEA & 2 & $0.267(0.017)$ & $0.239(0.020)$ & 1.06 \\
$D O W N$ & $0.255(0.013)$ & $0.702(0.018)$ & $0.643(0.022)$ & $2.06^{* *}$ \\
$P R O F I T_{\mathrm{i}}$ & $0.678(0.014)$ & $47.2(8.31)$ & $24.5(5.53)$ & $2.06^{* *}$ \\
$(Q / L-W / L)_{I}$ & $37.9(5.42)$ & $0.542(0.022)$ & $0.452(0.021)$ & $2.78^{* * *}$ \\
$(Q-W)_{i}$ & $0.505(0.016)$ & $505.4(61.07)$ & $238.9(23.63)$ & $3.50^{* * *}$ \\
$M K S H A R E_{i}$ & $396.8(37.62)$ & $0.024(0.002)$ & $0.013(0.002)$ & $3.53^{* * *}$ \\
$E M P G R$ & $0.020(0.002)$ & $-11.11(0.160)$ & $-11.18(0.195)$ & -0.286 \\
Number of & $-11.14(0.124)$ & 664 & 457 & -
\end{tabular}

Standard deviations of means are in parentheses.

Note: Profits, value of total output, wage bill, firm sales, and industry sales are measured in millions of 1992 Czech crowns, where 1 US dollar was equal to about 30 Czech crowns at the time. The firm-specific variables are calculated using annual 1992 observations and are denoted by an $i$ subscript.

** Significant at the 5 percent level.

*** Significant at the 1 percent level.

probability for an infinitesimal change in each independent, continuous variable and, the discrete change in the probability for the dummy variables. The standard errors of these effects are reported in the table. We also report the Wald and likelihood-ratio test statistics from the Rivers and Vuong (1988) exogeneity tests jointly and individually for the annual firm-specific variables in each specification. As mentioned earlier, we reject the null hypothesis of exogeneity for the accounting profits variable only, and in column 4 we treat accounting profits as endogenous. ${ }^{34}$

In column 1 of Table 3, both $C M E A$ and $D O W N$ have positive and statistically significant coefficients (at the 10 percent and 1 percent levels, respectively), as predicted by the GS model. The coefficient of the variable measuring the difference between the value of the average product of labor and the average wage, $(Q / L-W / L)_{i}$, has a positive sign and is also statistically significant. The results suggest that if a firm was moved from the 10 th percentile to 90 th percentile of $(Q / L-W / L)_{i}$, the probability of privatization would rise from .462 to .632 , or by almost $40 \%$, when the other variables are set at their mean values. This result is consistent with the government minimizing political costs, as well as maximizing privatization revenues and public goodwill; it is inconsistent with the government maximizing Pareto efficiency.

The coefficient on the market share variable captures two effects. While dead-weight loss may be lower if firms with monopoly power are not privatized early (as recommended by

\footnotetext{
${ }^{34}$ For the sake of completeness, we also estimated the probit equations using the first quarter 1992 data, rather than annual 1992 data, for the firm-specific variables. These estimates are similar to those based on annual data and we report them in Appendix Table A2. The only difference is that the coefficient on accounting profits is not statistically significant, perhaps because this variable is subject to seasonal fluctuations.
} 
Table 3

Estimating the probability of privatization.

The dependent variable equals one if the firm is privatized in the first wave: Firm-specific RHS variables are annual 1992 observations

\begin{tabular}{|c|c|c|c|c|}
\hline Variable & 1 & 2 & 3 & 4 \\
\hline CMEA & $\begin{array}{l}0.063^{*} \\
(0.035)\end{array}$ & $\begin{array}{l}0.071 * * \\
(0.035)\end{array}$ & $\begin{array}{l}0.061^{*} \\
(0.035)\end{array}$ & $\begin{array}{l}0.065^{*} \\
(0.035)\end{array}$ \\
\hline$D O W N$ & $\begin{array}{l}0.092 * * * \\
(0.034)\end{array}$ & $\begin{array}{l}0.104^{* * * *} \\
(0.034)\end{array}$ & $\begin{array}{l}0.103^{* * *} \\
(0.034)\end{array}$ & $\begin{array}{l}0.104 * * * \\
(0.034)\end{array}$ \\
\hline$M K S H A R E_{\mathrm{i}}$ & $\begin{array}{l}1.252^{* * * *} \\
(0.361)\end{array}$ & $\begin{array}{l}0.730^{*} \\
(0.396)\end{array}$ & $\begin{array}{l}1.223 * * * \\
(0.377)\end{array}$ & $\begin{array}{l}1.104 * * \\
(0.384)\end{array}$ \\
\hline$E M P G R$ & $\begin{array}{l}-0.0004 \\
(0.004)\end{array}$ & $\begin{array}{l}0.002 \\
(0.004)\end{array}$ & $\begin{array}{l}0.004 \\
(0.004)\end{array}$ & $\begin{array}{l}0.003 \\
(0.004)\end{array}$ \\
\hline$(Q / L-W / L)_{i} \times 10^{-4}$ & $\begin{array}{l}0.780 * * \\
(0.333)\end{array}$ & - & - & - \\
\hline$(Q-W)_{i} \times 10^{-7}$ & - & $\begin{array}{l}1.04 * * * \\
(0.312)\end{array}$ & - & - \\
\hline PROFIT $_{i} \times 10^{-7}$ & - & - & $\begin{array}{l}1.83 \\
(1.30)\end{array}$ & $\begin{array}{l}3.459 * \\
(1.678)\end{array}$ \\
\hline $\begin{array}{l}\text { Rivers and Vuong LR joint test for exogeneity } \\
\text { of firm-specific variables: } \chi_{(2)}^{2}\left(\text { Prob }>\chi_{(2)}^{2}\right) \\
\text { Rivers and Vuong Wald individual tests for } \\
\text { exogeneity } \chi_{(1)}^{2}\left(\text { Prob }>\chi_{(1)}^{2}\right)\end{array}$ & $\begin{array}{l}0.43 \\
(0.806) \\
(Q / L-W / L)_{i} \\
0.32 \\
(0.573) \\
M K S H A R E_{i} \\
0.06 \\
(0.799)\end{array}$ & $\begin{array}{l}0.80 \\
(0.671) \\
(Q-W)_{i} \\
0.59 \\
(0.442) \\
M K S H A R E_{i} \\
0.01 \\
(0.937)\end{array}$ & $\begin{array}{l}3.49 \\
(0.175) \\
P R O F I T_{i} \\
3.10^{*} \\
(0.078) \\
M K S H A R E_{i} \\
0.43 \\
(0.512)\end{array}$ & \\
\hline
\end{tabular}

Note: The reported coefficients provide the marginal effect or the change in the probability for an infinitesimal change in each independent, continuous variable and, the discrete change in the probability for the dummy variables. In columns 1-3 the firm-specific variables (denoted by an $i$ subscript) are treated as exogenous. In column 4, annual profit is treated as endogenous. The first stage results are reported in Appendix Table A1. A constant is included but not reported. The sample contains 1121 firms. See notes to Table 2. Standard errors are in parentheses.

GS), this variable may also proxy profitability. Hence, in the case of a Pareto efficiency maximizing government we expect the estimated coefficient to have a negative sign. However, if the government is primarily concerned with revenues and public goodwill then the estimated coefficient should have a positive sign. We find a positive and statistically significant coefficient on market share, suggesting that the latter objectives dominate.

Further, the coefficient on the industry employment growth variable, which measures labor demand conditions affecting political costs, is not statistically significant at standard confidence levels, casting doubt on the political costs model. As a result, we attribute the positive coefficients on the profit variables to revenue or public goodwill maximization.

In column 2 of Table 3 we use market share and the difference between the value of total output and the wage bill as proxies for profitability. These results are quite similar to those in column 1. These results imply that if a firm was moved from the 10 th percentile to 90 th percentile of $(Q-W)_{i}$, the probability of privatization would rise from .558 to .658 , or by almost twenty percent. In column 3 we replace the difference between the value of total output and the wage bill with accounting profits. The results are similar to those in columns 1 and 2 except that the coefficient on accounting profits has a statistically 
insignificant coefficient. However, the null hypothesis that this variable is exogenous is rejected. Thus, in column 4 we treat accounting profits as endogenous. The results are similar to those in columns 1 through 3 , although treating accounting profits as endogenous substantially increases its coefficient and statistical significance. ${ }^{35}$ (Treating accounting profits as endogenous has little effect on the other coefficients.) These results imply that if a firm was moved from the 10th percentile to 90th percentile of accounting profits, the probability of privatization would rise from $46.4 \%$ to $63.4 \%$, an increase of about $37 \%$.

Finally, to examine the possibility that Eqs. (6), (7), and (8) are too rich to identify the effect of the employment growth variable, we consider a narrower specification that eliminates the industry dummy variables $C M E A$ and $D O W N$. These results are quite similar to those in Table 3, and the coefficient of the employment growth variable remains statistically insignificant. ${ }^{36}$ As noted earlier, one possible explanation is that the relatively low level of variation in this variable across industries leads to an insignificant coefficient on this variable.

\section{Conclusion}

In the numerous privatization programs around the world, governments have virtually never privatized all firms simultaneously. This raises the issue of how governments sequence privatizations strategically on the basis of their objectives. Many economists would see increasing Pareto efficiency as a primary goal of governments. Glaeser and Scheinkman (1996) suggest that governments may maximize the efficient flow of information in the economy. We discuss additional theories of privatization that relate to other government objectives as seen by economists, political scientists and sociologists: Maximizing public goodwill, minimizing political costs, and maximizing privatization revenues. These models provide concrete predictions about the sequencing of privatization in any transitional economy. We test these predictions using micro-data from the Czech large-scale privatization program.

We find strong evidence that the Czech government privatized first firms that were more profitable, firms in downstream industries, and firms in industries subject to greater demand uncertainty. Privatizing more profitable firms first is inconsistent with maximizing Pareto efficiency, but it is consistent with the government objectives of maximizing privatization revenues and public goodwill. On the other hand, while a government minimizing political costs of unemployment may also privatize profitable firms first, the other important implication of the political cost model that employment growth in the firm's industry should affect sequencing is not supported by our data, which weakens support for the political cost objective considerably. Our finding that firms in downstream industries and in industries with greater demand uncertainty were more likely to be privatized early suggests that this privatization strategy improved the responsiveness of SOEs to market shocks, increasing efficiency due to informational gains (Glaeser and Scheinkman, 1996). However, in contrast to the GS prediction but consistent with the general evidence regarding profitability, firms with higher market share were more likely to be privatized first.

\footnotetext{
${ }^{35}$ One could argue that variables such as $P$ ROFIT $i$ or $(Q-W)_{i}$ may simply be picking up a size effect, although there is no theoretical reason to include size. Our results, however, are very similar when we use $(Q / L-W / L)_{i}$, which is independent of firm size.

${ }^{36}$ The results are available upon request.
} 
In future work it will be useful to use data from other transitional economies to examine these objectives in countries other than the Czech Republic. Such estimation and testing will build a body of knowledge concerning the actual priorities of governments in these economies. Since many of these countries will have more variable employment growth than the Czech Republic, this will also allow researchers to better assess the role of political costs in these economies. Needless to say, other complications will arise as one considers data from other economies. For example, manager and worker buyouts were fairly common in Russia, where about $55 \%$ of firms were sold by this method (World Bank, 1996). For these cases of insider privatization it may not be easy to predict the government's sequencing priorities, since privatization could be an outcome of joint bargaining between the government, managers, and workers.

Evidence from other countries suggests that our framework is relevant in general for investigating government objectives in privatization. For example, Dinc and Gupta (2006) find that in India more profitable firms are likely to be sold earlier than others. Further, government objectives in privatization have been shown to be relevant for the Polish privatization program (De Fraja and Roberts, 2007), and for Chinese privatization (Guo and Yao, 2005).

In addition to providing key evidence on the nature of the privatization process, our results have important implications for studies evaluating the effect of privatization. Many of these studies measure gains from privatization by comparing the performance of privatized firms to firms that are still in the public sector. Such comparisons are valid only if firms are randomly chosen for privatization. For example, if the government selectively privatizes better firms (as our results suggest), it would not be surprising to see these privatized firms perform better than firms that remain public, even if privatization had no effect on firm performance. Thus, our results suggest that it is necessary to investigate the possibility of selection bias (Heckman, 1979) in such an evaluation. A similar statistical problem arises in studies examining the effect on firm performance of the length of time since privatization. Our result that more profitable firms are likely to be privatized early implies that unobserved characteristics that make the firms more profitable may be correlated with the length of time they have been privatized. ${ }^{37}$

\section{Acknowledgments}

We are grateful to Daniel Berkowitz, David Brown, Curtis Eberwein, Esther Gal-Or, Rick Harbaugh, Stepan Jurajda, James Peck, and three anonymous referees for many helpful comments and discussions. We would also like to thank The Center for Economic Research and Graduate Education-Economics Institute (CERGE-EI) for making the data available. Some of this research was conducted while Ham was a visitor at the Federal Reserve Bank of New York and he thanks the Bank for providing a hospitable and productive environment. This project was supported in part by NSF Grants SBR-9512001 and SBR-9809546, and we are grateful for the support. Any opinions, findings, and conclusions or recommendations in this material are those of the authors and do not necessarily reflect the views of the National Science Foundation, the Federal Reserve Bank

\footnotetext{
${ }^{37}$ Evaluation based on 'difference in differences' will address this selection bias under fairly strong assumptions. The use of 'difference in difference' propensity score matching would allow the evaluation to be based on weaker assumptions. See Heckman et al. (1999).
} 
of New York, the Federal Reserve Bank of San Francisco or the Federal Reserve System. We are responsible for any errors.

\section{Appendix}

For first-stage estimates of annual 1992 and full model estimates of first quarter 1992 data, please see Tables A1 and A2.

Table A1

First stage estimates of the annual 1992 firm-specific variables

\begin{tabular}{|c|c|c|c|c|}
\hline \multirow{2}{*}{$\begin{array}{l}\text { Explanatory variables using } \\
\text { quarter } 1,1992 \text { observations } \\
\text { for firm-specific variables }\end{array}$} & \multicolumn{4}{|c|}{ Dependent variables using annual 1992 observations } \\
\hline & $(Q / L-W / L)_{i} \times 10^{-4}$ & $(Q-W)_{i} \times 10^{-7}$ & $M K S H A R E_{i}$ & PROFIT $_{i} \times 10^{-7}$ \\
\hline$C M E A \times 10^{-3}$ & $\begin{array}{l}0.280 \\
(1.091)\end{array}$ & $\begin{array}{l}-0.075 \\
(1.91)\end{array}$ & $\begin{array}{l}-0.148 \\
(0.754)\end{array}$ & $\begin{array}{l}0.477 \\
(0.843)\end{array}$ \\
\hline$D O W N \times 10^{-3}$ & $\begin{array}{l}0.083 \\
(1.030)\end{array}$ & $\begin{array}{l}-1.852 \\
(0.181)\end{array}$ & $\begin{array}{l}-0.730 \\
(0.711)\end{array}$ & $\begin{array}{l}-0.017 \\
(0.795)\end{array}$ \\
\hline$M K S H A R E_{i}$ & $\begin{array}{l}0.003 \\
(0.011)\end{array}$ & $\begin{array}{l}-0.017 \\
(0.019)\end{array}$ & $\begin{array}{l}0.958 * * * \\
(0.008)\end{array}$ & $\begin{array}{l}-0.027 * * * \\
(0.008)\end{array}$ \\
\hline$E M P G R \times 10^{-4}$ & $\begin{array}{l}9.156 * * * \\
(1.226)\end{array}$ & $\begin{array}{l}2.196 \\
(2.150)\end{array}$ & $\begin{array}{l}-0.525 \\
(0.847)\end{array}$ & $\begin{array}{l}0.157 \\
(0.947)\end{array}$ \\
\hline$(Q / L-W / L)_{i} \times 10^{-4}$ & $\begin{array}{l}3.665^{* * * *} \\
(0.038)\end{array}$ & $\begin{array}{l}-0.015 \\
(0.066)\end{array}$ & $\begin{array}{l}-0.020 \\
(0.026)\end{array}$ & $\begin{array}{l}-0.009 \\
(0.029)\end{array}$ \\
\hline$(Q-W)_{i} \times 10^{-7}$ & $\begin{array}{l}0.021 \\
(0.020)\end{array}$ & $\begin{array}{l}4.075 * * * \\
(0.034)\end{array}$ & $\begin{array}{l}0.048 * * * \\
(0.014)\end{array}$ & $\begin{array}{l}0.384 * * * \\
(0.015)\end{array}$ \\
\hline $\mathrm{PROFIT}_{i} \times 10^{-7}$ & $\begin{array}{l}-0.285^{* *} \\
(0.124)\end{array}$ & $\begin{array}{l}-2.156^{* * *} \\
(0.218)\end{array}$ & $\begin{array}{l}-0.312^{* * *} \\
(0.086)\end{array}$ & $\begin{array}{l}1.030 * * * \\
(0.096)\end{array}$ \\
\hline$R^{2}$ & 0.919 & 0.956 & 0.958 & 0.585 \\
\hline Number of observations & 1121 & 1121 & 1121 & 1121 \\
\hline
\end{tabular}

Note: Dependent variables are the annual observations from 1992. The right-hand side firm-specific variables, denoted by an $i$ subscript, are observations from the first quarter of 1992. All equations include a constant (not shown). See notes to Table 2.

Standard errors are in parentheses.

Table A2

Estimates of the full model using first quarter 1992 data

\begin{tabular}{llll}
\hline Variable & 1 & 2 & 3 \\
\hline$C M E A$ & $0.063^{*}(0.035)$ & $0.070^{* *}(0.035)$ & $0.058^{*}(0.035)$ \\
DOWN & $0.092(0.034)$ & $0.102^{* * *}(0.034)$ & $0.099 * * *(0.034)$ \\
$M K S H A R E_{i}$ & $0.468^{* * *}(0.140)$ & $0.294^{*}(0.155)$ & $0.497 * * *(0.145)$ \\
$E M P G R$ & $0.001(0.004)$ & $0.002(0.004)$ & $0.004(0.004)$ \\
$(Q / L-W / L)_{i} \times 10^{-4}$ & $2.576^{* *}(1.284)$ & - & - \\
$(Q-W)_{i} \times 10^{-7}$ & & $0.315^{* * *}(0.113)$ & - \\
$P R O F I T_{i} \times 10^{-7}$ & - & - & $0.015(0.034)$ \\
\hline
\end{tabular}

Note: Firm-specific variables are observations from the first quarter of 1992. The reported coefficients provide the marginal effect or the change in the probability for an infinitesimal change in each independent, continuous variable and, the discrete change in the probability for the dummy variables. See notes to Table 2 and Table A1. Standard errors are in parentheses. 


\section{References}

Aghion, P., Blanchard, O., 1994. On the speed of transition in Central Europe. NBER Macroeconomics Annual, pp. 283-320.

Barberis, N., Boycko, M., Shleifer, A., Tsukanova, N., 1996. How does privatization work? Evidence from the Russian Shops. Journal of Political Economy 104, 764-790.

Bilsen, V., Konings, J., 1998. Job creation, job destruction, and growth of newly established, privatized, and stateowned enterprises in transition economies: Survey evidence from Bulgaria, Hungary, and Romania. Journal of Comparative Economics 26, 429-445.

Bohata, M., Hanel, P., Fischer, M., 1995. Performance of manufacturing. In: Svejnar, J. (Ed.), The Czech Republic and Economic Transition in Eastern Europe. Academic Press, San Diego, CA.

Chakraborty, A., Harbaugh, R., Gupta, N., 2006. Best foot forward or best for last in a sequential auction? Rand Journal of Economics 37, 176-194.

Claessens, S., Djankov, S., 1999. Ownership concentration and corporate performance in the Czech Republic. Journal of Comparative Economics 27, 498-513.

Claessens, S., Djankov, S., Pohl, G., 1997. Determinants of performance of manufacturing firms in seven European transition economies. William Davidson Institute Working Paper, No. 74.

De Fraja, G., Roberts, B., 2007. Privatization in Poland: What was the government trying to achieve? CEPR Working Paper, No. 6114.

Dewatripont, M., Roland, G., 1995. The design of reform packages under uncertainty. American Economic Review 85, 1207-1223.

Dinc, S., Gupta, N., 2006. The decision to privatize: Finance, politics, and patronage. Indiana University Working Paper.

Djankov, S., Murrell, P., 2002. Enterprise restructuring in transition: A quantitative survey. Journal of Economic Literature 40, 739-792.

Dyba, K., Svejnar, J., 1995. A comparative view of economic developments in the Czech Republic. In: Svejnar, J. (Ed.), The Czech Republic and Economic Transition in Eastern Europe. Academic Press, San Diego, CA.

Dyck, A., 1997. Privatization in Eastern Germany: Management selection and economic transition. The American Economic Review 87 (4), 565-597.

Estrin, S., Hanousek, J., Kocenda, E., Svejnar, J., 2007. Effects of privatization and ownership in transition economies. Mimeo, LSE-University of Michigan.

Frydman, R., Gray, C.W., Hessel, M., Rapaczynski, A., 1999. When does privatization work? The impact of private ownership on corporate performance in transition economies. Quarterly Journal of Economics 114, 1153-1191.

Guo, K., Yao, Y., 2005. Causes of privatization in China: Testing several hypotheses. The Economics of Transition 13, 211-238.

Glaeser, E.L., Scheinkman, J.A., 1996. The transition to free markets: Where to begin privatization. Journal of Comparative Economics 22, 23-42.

Grosfeld, I., Nivet, J.F., 1997. Firm's heterogeneity in transition: Evidence from a Polish panel data set. Working Paper, The William Davidson Institute.

Hartley, H.O., Sielken, R.L., 1975. A 'super-population viewpoint' for finite population sampling. Biometrics 31 , 411-422.

Hashi, I., Mladek, J., Sinclair, A., 1997. Bankruptcy and owner-led liquidation in the Czech Republic. In: Balcerowicz, L., Gray, C.W., Hashi, I. (Eds.), Enterprise Exit Processes in Transition Economies: Downsizing, Workouts and Liquidations. CEU Press, London.

Heckman, J., 1979. Sample selection bias as a specification error. Econometrica 47, 153-161.

Heckman, J., LaLonde, R., Smith, J., 1999. The economics and econometrics of active labor market programs. In: Ashenelter, O., Card, D. (Eds.), The Handbook of Labor Economics. Elsevier, Amsterdam.

Katz, B., Owen, J., 1993. Privatization: Choosing the optimal time path. Journal of Comparative Economics 17 , $715-736$.

Kikeri, S., Nellis, J., Shirley, M., 1992. Privatization: The Lessons of Experience. The World Bank, Washington, DC.

Kotrba, J., 1995. Privatization process in the Czech Republic: Players and winners. In: Svejnar, J. (Ed.), The Czech Republic and Economic Transition in Eastern Europe. Academic Press, San Diego, CA.

Megginson, W., 2005. The Financial Economics of Privatization. Oxford University Press, New York, NY. 
Megginson, W., Netter, J.M., 2001. From state to market: A survey of empirical studies on privatization. Journal of Economic Literature 39, 321-389.

Mejstrik, M., Marcincin, A., Lastovicka, R., 1997. Voucher privatization, ownership structures, and the emerging capital market in the Czech Republic. In: Mejstrik, M. (Ed.), The Privatization Process in East-Central Europe: Evolutionary Process of Czech Privatizations. Kluwer Academic Publishers, Norwell, MA.

Perotti, E., 1995. Credible privatization. American Economic Review 85, 847-859.

Perotti, E., Guney, S., 1993. Successful privatization plans. Financial Management 22 (1), 84-98.

Prasnikar, J., Svejnar, J., Mihlajek, D., Prasnikar, V., 1994. Behavior of participatory firms in Yugoslavia: Lessons for transition economies. Review of Economics and Statistics 76, 728-741.

Rivers, D., Vuong, Q.H., 1988. Limited information estimators and exogeneity tests for simultaneous probit models. Journal of Econometrics 39, 347-366.

Roland, G., 2000. Transition and Economics: Politics, Markets and Firms. MIT Press, Cambridge, MA.

Sabirianova Peter, K., Svejnar, J., Terrell, K., 2005. Foreign investment, corporate ownership and development: Are firms in emerging markets catching up to the world standard? IZA Working Paper No. 1457.

Svejnar, J., 1982. On the theory of a participatory firm. Journal of Economic Theory 27, 313-330.

Svejnar, J., 1986. Bargaining power, fear of disagreement and wage settlements: Theory and evidence from US industry. Econometrica 54, 1055-1078.

The World Bank, 1996. World Development Report 1996, Washington, DC.

The World Bank, 1999. Czech Republic: Toward EU Accession. Washington, DC. 